\section{Civic programmatic participation in public health: the case of Argentina}

\author{
Participación cívica en programas de salud \\ pública: el caso de Argentina \\ Participação programática cidadã na saúde \\ pública: o caso da Argentina
}

Tulia G. Falleti 1

Santiago L. Cunial 1

doi: $10.1590 / 0102-311 \times 00243218$

\begin{abstract}
Since the Alma Ata World Health Organization Conference in 1978, countries around the world have adopted institutions that promote the participation of citizens in their public health systems. The main objectives of this article are two-fold. First, we describe the origins and implementation of a nationallevel civic participatory program that was in place in Argentina in the mid2000s: the Local Participatory Projects (Proyectos Locales Participativos). Second, we analyze the 201 local participatory projects that were carried out in Argentina between 2007 and 2008. We study health and environmental problems that prompt people's participation in the program and the social dynamics through which such participation is executed.
\end{abstract}

Community Participation; Health Planning; Local Government;

Health Policy

\section{Correspondence}

T. G. Falleti

University of Pennsylvania.

133 S. 36th Street, PCPSE, Office 324, Philadelphia,

Pennsylvania 19104, USA.

falleti@upenn.edu

1 University of Pennsylvania, Philadelphia, USA. 


\section{Introduction}

Since the Alma Ata World Health Organization Conference in 1978, a number of countries around the world have adopted institutions to promote the participation of citizens in their public health sectors. The scope of civic activities is quite varied, ranging from simply informing or consulting the population about health programs, to requiring and incorporating their input in policy design, monitoring health services, and in some cases to jointly execute policies for public health programs 1 .

Although health is a defining feature of life and minimal health conditions are necessary for human functioning, little attention has been paid to health policies within political science 2 , in particular within the literature on citizen participation. The recent literature on community participation has focused on educational councils 3 , security councils 4 , and water basin councils 5 , among other local, regional, and national participatory institutions 6 . The first goal of this article is to describe the origins and implementation of a national-level civic participatory program that was placed in Argentina in the mid-2000s: the Local Participatory Projects (Proyectos Locales Participativos). The program was largely conceived and designed by public administrators and primary health care doctors that had been working on community projects at the provincial and local level for some time. The program was made possible by a political context that favored popular participation and primary health care. The second goal is to advance our understanding on health and environmental problems that prompt people's participation as well as the dynamics through which such participation is executed.

In this context, we analyze the case of civic participation in Argentina in the contexts of programmatic participation 1 . We define programmatic participation as an institutionally organized and state sanctioned individual or collective behavior that influences or attempts to influence the management or distribution of public goods or social services, such as public budgets, schools, health clinics, or the environment. This is to say, this is not a participation that seeks to gain individual access to services or goods, such as the case of clientelistic exchanges where political support is provided to gain individual access to either public or quasi-market social services. Programmatic participation is voluntary behavior, but unlike broader definitions of civic engagement or volunteering, we are interested in programmatic participation that is sanctioned, promoted, or at least institutionally recognized by the state. This type of participation can, in turn, promote different types of civic activities, among which we distinguish consultation, planning, monitoring, and execution.

The article is organized as follows. In the next section, we describe the institutional origins of civic participation in public health in Argentina. The third section explains how the Local Participatory Projects program came about. In the fourth section we analyze the 201 local participatory projects that were carried out from mid 2007 to mid 2008. Among other topics, we outline the public health problems tackled by communities, the characteristics of the participants, and some of the features found among those communities that participated more frequently throughout the year. The fifth section accounts for the program's dismissal, and the final section summarizes the main findings, outlines future research questions and some of the policy implications of the Argentinian experience.

\section{The institutional origins of civic participation in public health in Argentina}

During the 20th century, Argentina's health system evolved into a fragmented system with three subsystems: the public sector, which offers free health services through its network of hospitals and primary care health clinics; the social insurance sector of the so-called obras sociales, for the formal workers of the economy and retirees; and the private health insurance sector. In 2010, according to the National Statistics and Censuses Institute of Argentina (INDEC, for its acronym is Spanish), 46\% of the population was covered by obras sociales, $15.6 \%$ by the private health sector, and the remaining $38.4 \%$ of the population was covered exclusively by the public system. It is this last portion of the Argentinian population, who relies in the public health care system, that this paper will focus on.

At the time of the Alma Ata conference, in 1978, Argentina was in the second year of its most violent and repressive military dictatorship. Decentralization of national health services towards the provinces started at that time and continued in 1991, during the period of neoliberal economic reforms $7,8,9,10,11$. As the military government was offloading health services onto sub-national 
governments, it also adopted the label of primary health care (PHC) to refer to the territorial-based programs of health care, sanitation, and disease prevention that had been in operation since the 1960s. These programs had developed in rural areas, particularly in the Northwestern provinces of Jujuy, Salta, and Tucumán (around the production of sugar, cotton, and tobacco), in the province of Neuquén, and in the suburban and poor peripheries of large urban centers, such as Buenos Aires. Other than creating the PHC label to refer to these primary health care programs, the military government actively discouraged community participation. In fact, the authoritarian regime considered the activities related to the promotion of community participation in health care to be "subversive", and hence subject to its systematic state repression. A health agent working at the time in the department of Güemes, in the northern province of Salta, expressed this state of affairs very eloquently: “... in 1978, primary health care is born (...) with one condition: without community participation. It was very clear. We could do anything we wanted, but without participation. Come on, please [it was said at the time] you shall not promote subversion..." 12 (p. 368).

With the transition to democracy in 1983, some social programs directed to vulnerable populations begun to promote community participation. However, they remained highly localized and outside of the purview of the Ministry of Health. In fact, towards the end of the first democratic transition government of President Raúl Alfonsín (1983-1989), the idea that community participation in health was part of a leftist and subversive political agenda was still deeply rooted among sectors of society, and in particular among the federal and provincial security forces. Dr. Carlos Anigstein, a pediatrician and primary care doctor, who worked on APS at the time, told us (Anigstein C, Buenos Aires, 28/ Dec/2017; personal communication):

"Although it may be hard to believe, when I was in the hospital [Ramón Carrillo, in the province of Buenos Aires], two car bombs were placed in my car and I received death threats. I have a Jewish surname (...) 'We are going to kill you, judio de mierda'. But then, when the federal police came and when the security intelligence services came, they would tell me 'What do you expect, Doctor? Considering the work you do (...)'. For them, anything having to do with participation was subversive (...) Even though we were in 1989 [six years into the democratic government]".

It was only after the 2001 economic and political crisis, that community participation in health entered the national government's agenda, largely as a way to address the immediate post-crisis health care needs of the most vulnerable social sectors. Community participation in monitoring (first) and planning (later) the health programs and projects was also inspired by the inclusionary ideology of policy designers who became policy makers at the federal level. Some of these policy makers had been working in primary health care since the early 1970s and had been deeply influenced by the participatory experiences in Cuba (in the 1960s) and Brazil (since the late 1980s).

During the administration of Dr. Ginés González García as National Minister of Health and Environment (2002-2007), those (now national-level) policy makers promoted community participation in a federal network of primary and preventive health care programs. Among the policy makers who designed participatory policies were Dr. Carlos Pacheco, Dr. Carlos Anigstein, and Sociologist Federico Tobar. These national-level programs included, among others, the Programa REMEDIAR (2002-2017), the Médicos Comunitarios program, the Municipalidades Saludables program, and the Proyectos Locales Participativos program, which we analyze.

REMEDIAR, a program for the distribution of free medicine through the public primary health care clinics (Primary Health Care Centers - PHCC), was the stewardship of these programs. It was designed to address some of the daring needs of the population after the 2001 economic crisis. It consisted in the delivery of commonly prescribed and generic drugs for the distribution among PHCC patients throughout the Argentinian territory. By 2006, the program distributed boxes of generic drugs (botiquines) to approximately 5,000 PHCC throughout the country 11. In 2007, in its fifth anniversary, the program produced a descriptive video, Remediar 5 Años (https://youtu.be/OTEEzZMekio). By the year 2012 (when the program was in its 10th running year), President Cristina Fernandez de Kirchner (2007-2015) distributed the botiquin number 1,500,000 13. In the national offices of the Ministry of Health, REMEDIAR was run by a relatively small and highly trained group of young professionals and experts (some of them political scientists and sociologists). They were mindful about social needs and inequities in the distribution of public health benefits, and sought to address issues of efficiency in public spending (through bulk purchase of generic drugs, for instance) and in the delivery of these 
drugs to patients, such that the medicines (or botiquines) would reach the CAPS and their patients. To curve possible deviation of these resources, civil society organizations were invited to participate as monitors of the program.

As a health care program, REMEDIAR is particularly salient for several reasons. First, it was (to our knowledge) the first national level program to promote civic engagement in health policies. The program had ten explicit goals; among them were: strengthening primary health care, direct distribution of medicines, direct social control, participation, and transparency 13. Even if at the beginning of the program, civil society engagement was limited to the role of monitoring (society as watchdogs of local officials that the central government cannot fully monitor), such participation extended over time to other types, involving planning and executing, as we explain below. Second, REMEDIAR is important because it was the longest running program among those that fomented participation, surviving through several presidential administrations (from Eduardo Duhalde, to Néstor Kirchner and Cristina Fernández de Kirchner). Third, it fostered the implementation of other participatory programs, such as the Local Participatory Projects.

Civic community involvement in the REMEDIAR program was primarily as monitors. Civil society organizations and individuals worked as "watchdogs" that the nationally provided botiquines were reaching the PHCC' patients and not being diverted to other uses or being distributed by political personnel in exchange for political support. This type of community monitoring was described as "social direct control" (Casabal A, Buenos Aires, 16/Jul/2009; personal communication/Monsalvo LM, Buenos Aires, 16/Jul/2009; personal communication). The ministry worked with Caritas (a Catholic organization) and the Red Cross (a non-religious denomination institution) both at the central level and in the localities.

Closely related to the REMEDIAR program, the Local Participatory Projects program sought to augment civic participation in health, not only in the monitoring role of participation, but also in the planning (planificación participativa) and in the execution. The program's origins are found in 2004, when the area dedicated to the participation of the REMEDIAR program put out a call for community health narratives (or relatos) from PHCC.

As the narratives started to pour into the central offices of the National Health Ministry, the personnel who read the narratives realized that many of them (whether in the form of letters, short stories, or photo compositions) were in fact presenting projects to work with the community or to improvethe PHCC (Casabal A, Buenos Aires, 16/Jul/2009; personal communication). In fact, the narratives were so many and so interesting that they gave awards to some in a national event. It was then that the idea of putting out a call for community participation proposals through the PHCC started to take shape. Such an idea found fertile institutional ground that those leading the Ministry liked it and were willing to support it. This is to say, political support for this project at the leadership level in the Ministry of Health was fundamental for the project's birth. Such support, or lack thereof, also explained the future instability of the program, as described below.

\section{Local Participatory Projects in public health}

The first call for proposals took place in 2006. At the national level, the Local Participatory Projects program was led by three social workers highly committed to the ideas of community participation and civic engagement: Andrea Casabal (the only member of the team who was still working in the National Ministry after 2011), Cristina Ruano, and Daniel Ventura. They worked in close collaboration with the REMEDIAR program, which already had expertise with thousands of primary health care centers throughout the country. Three hundred and sixty nine projects were presented to the ministry that year. With funding from an international loan, 198 projects were selected and financed. The projects were distributed throughout 23 of the provinces and the city of Buenos Aires, Argentina (only the most southern province of Tierra del Fuego did not have a participatory project that year).

The 2006 call for proposals had a carefully crafted series of guidelines about community participatory planning, specifically on how to prioritize health and sanitation problems to be tackled by the community and the PHCC personnel throughout the program. The problem prioritization model was one of the steps of the guidelines and it is worth describing it, as these problems are excellent descrip- 
tors of the socioeconomic context of the communities carrying out the Local Participatory Projects. For each problem that the community identified, six questions had to be asked and the answers scored between 0 and 4: (1) "How many of the population in this social group are affected by this problem?"; (2) "What is the expected trend for the upcoming years?"; (3) "What is the likelihood of this problem generating important harm?"; (4) "What is the likelihood of preventive actions reducing this harm?"; (5) "What are the type of solutions that exist: Institutionally? Financially? Communally?"; (6) "What is the community's degree of interest in solving the problem?".

Thus, in a meeting with the PHCC' health agents, the members of the civil society gathered to identify the most pressing problems in their communities and rank them according to these criteria. The use of boards or posters was encouraged to track the problems and the scores of the questions (for the illiterate population these problems were represented by hand-drawn images). The communities were also encouraged to brainstorm in boards and posters the root causes of the problems identified and distinguish among those that could be addressed by the community's involvement in this program and those that were not addressable. For example, while the lack of receptacles for trash disposal was an addressable cause, the inadequate service of trash collection in the locality was not.

The national ministry team produced a video entitled Protagonistas with interviews with health agents and community members of seven of these projects in five Argentinian provinces. The first project presented in the video, from the PHCC Las Pircas, in the municipality of La Merced, Salta, depicts the use of posters and drawings to identify problems (presumably because at least part of the population of the PHCC catchment is illiterate), prioritize them, following the guidelines, and brainstorm about the addressable causes of those problems. In that community, the prioritized problem was water treatment (the project was entitled Agua y Vida).

All the seven cases recorded in the video, portray participant communities that are poor or extremely poor. In the case of the community project in Godoy Cruz, Mendoza, for instance, all the members of the community live from scavenging in a nearby dumping site. In the northern community of Rosario de Lerma, Salta, the participants in the project are mostly indigenous, and the communal project consisted of a vegetable garden. As a community member described in the video, the vegetable garden undertaken with the Local Participatory Projects "freed up money [in her household] to buy some fruits or some meat". In another community, in the locality of Trancas, Tucumán, the main problem addressed by the project was children undernourishment. One of the women of the civil society who participated in this project explained that the Local Participatory Projects had empowered her by teaching her how to provide nutritious meals for her children and educate other families on what she had learned: "I am proud of what I have done because my daughter was in the third degree of [severe] malnutrition and now she is normal".

The following year, the second call for Local Participatory Projects' proposals was out. The same guidelines were used to prioritize problems and identify addressable causes ${ }^{14}$. The funding for the 2007 Local Participatory Projects came from an Interamerican Development Bank (IADB) loan in 1,000,000 Argentinian Pesos (about USD 320,000) and 200 grants would be awarded in the amount 5,000 Argentinian Pesos (about USD 1,600) each. The ministry received 569 proposals, among which 201, as described below, were chosen following a careful double evaluation.

\section{The Local Participatory Projects of 2007-2008}

We chose to analyze the 2007-2008 Local Participatory Projects for several reasons. First, the 2007 call for proposals had a very clear set of guidelines from the National Ministry of Health (elaborated upon the previous year's guidelines) and for that reason the funded projects were very well-designed. The guidelines stated how the proposals had to be presented, and most importantly, how the community had to come up with the top-ranked problem related to public health (broadly defined, to include also environment and hygiene issues ) and how the community would seek to address such problem through the project. These guidelines also walked the PHCC personnel and communities through the ins and outs of participatory community planning. They were very explicit about how to arrive at a local community diagnosis of the community's most pressing problems, which could be addressed through community participation (as opposed to those that could not be addressed with these types of 
projects, such as unemployment or poverty). In terms of civil society activities, the Local Participatory Projects promoted consultation, planning, monitoring, and execution ${ }^{1}$. The recruitment was direct: any member of the community could participate. In fact, all health workers of the primary health care centers, professional and non-professional, were asked to work with community institutions and community members (vecinos). Finally, the guidelines also had clear criteria for what type of expenses were eligible and which expenses were not (for instance, only up to $20 \%$ of the budget could be allocated to human resources that were not part of the PHCC, PHCC personnel remuneration or PHCC infrastructure expenses were not eligible expenses).

The second reason that makes the 2007 Local Participatory Projects particularly worthy of analysis is that due to the fact that the call for proposals was extended to all the PHCC in Argentina, the 201 (one more than originally intended) funded projects were spread in localities throughout all the provinces of Argentina (Figure 1), instead of only in some of them, as it would be the case in future iterations of the Local Participatory Projects program.

\section{Figure 1}

Distribution of 2007 Local Participatory Projects in health, by locality. Argentina.

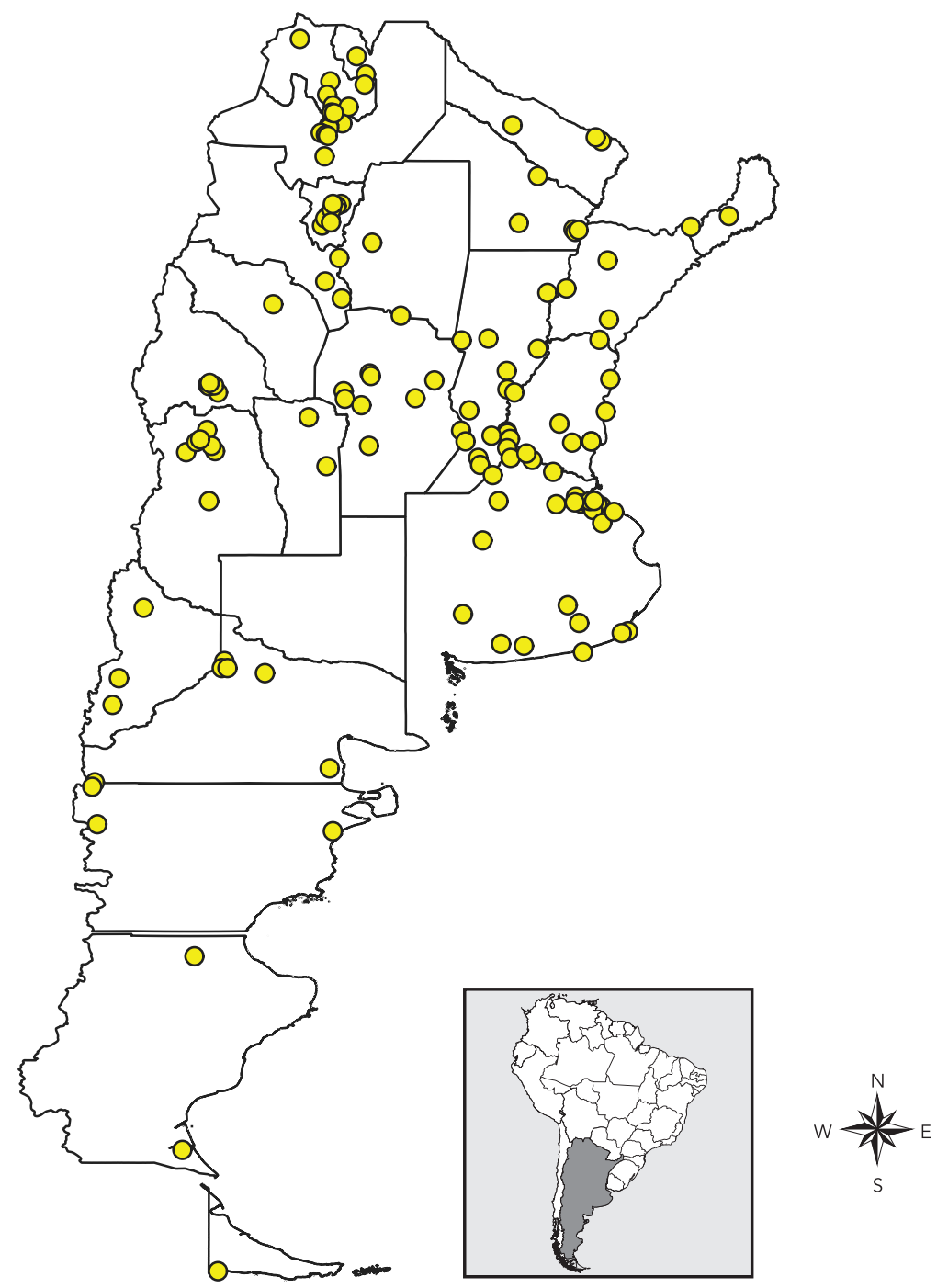


Finally, 2007 was the year which we could find the most information available in the offices and archives of the National Ministry of Health. The available information consisted of dozens of tworing 5-inch filing folders containing photocopies of the projects' proposals presented by the communities, the two independent project evaluations, the midterm progress evaluation, the final evaluation, and in 120 cases the minutes of all the meetings that took place in the communities in relation to the Local Participatory Projects projects, as well as some additional materials such as copies of receipts, and photos. All this information was available for the funded projects. One of the authors was allowed to consult and electronically compile that information. This data was then combined with data from a Ministry of Health census of PHCC of 2005.

The Ministry received 569 proposals in 2007. Out of those proposals, 201 were selected after two independent evaluations. One evaluator was from the leading Local Participatory Projects team in the National Ministry of Health. The other evaluator was either a member of the Red Cross or of Caritas (the two NGOs that had been working with the parent REMEDIAR program since 2002). The evaluation grid had a very clear criteria about how to evaluate each proposal. These included: (1) methodology used to design the Local Participatory Projects (up to 25 points); (2) community participation (up to 35 points); (3) sanitary relevance (up to 20 points); (4) likelihood of the project's continuity (up to 10 points, here whether there existed support from local authorities or other sources of financing, projects would get more points); (5) creativity as a contribution for PHC (up to 10 points). Each evaluator assigned a score between 0 and 100 for each proposal, by filling out each section of the 3-page evaluation questionnaire. The two evaluations were averaged. The top-ranking 201 proposals were selected for funding.

We reviewed and compiled the scores of all the double evaluations of the funded projects. The two evaluations' averaged scores for the funded projects varied from 60.5 to 98 points, with an average of 75.41 points. In regards to the evaluation of community participation (which could vary from 0 to 35 points), the average score was 25.15 , with a minimum value of 13.8 and a maximum of 35 points. Comparing to the community participation score given by the two evaluators (project participation score difference), the average difference was almost 3.1 points. These values are shown in Table 1, which also includes the summary statistics of all the other numerical variables analyzed in this section.

Everything in the archive materials of the ministry indicates that the evaluation process was based on merit and that there were no other considerations going into the decision of which projects to be funded. Although in an interview one of the members of the leading team recognized that they tried to have at least one proposal for each province. This can be appreciated in Figure 2, which represents, in

Table 1

Summary statistics.

\begin{tabular}{|c|c|c|c|c|c|}
\hline Variable & Mean & Minimum value & Maximum value & Standard deviation & $\begin{array}{l}\text { Number of } \\
\text { observations }\end{array}$ \\
\hline Project average score & 75.41 & 60.5 & 98 & 7.65 & 184 \\
\hline Project participation average score & 25.15 & 13.8 & 35 & 5.2 & 184 \\
\hline Project participation score difference & 3.07 & 0 & 15 & 3.42 & 183 \\
\hline Civil society participants in project & 8.53 & 0 & 39 & 5.63 & 184 \\
\hline Civil society women in project & 6.14 & 0 & 25 & 4.17 & 180 \\
\hline Civil society men in project & 2.38 & 0 & 14 & 2.51 & 180 \\
\hline Civil society participants in final report & 6.06 & 0 & 29 & 4.73 & 115 \\
\hline Civil society women in final report & 4.79 & 0 & 24 & 4.09 & 115 \\
\hline Civil society men in final report & 1.27 & 0 & 8 & 1.55 & 115 \\
\hline Number of meetings throughout year & 7.02 & 1 & 31 & 5.36 & 121 \\
\hline $\begin{array}{l}\text { Average number of civil society } \\
\text { participants in meetings }\end{array}$ & 4.53 & 0.11 & 31 & 4.49 & 118 \\
\hline Percentage of budget executed & 79.92 & 18.5 & 100 & 21.51 & 123 \\
\hline
\end{tabular}


Figure 2

Number of funded proposals per province. Argentina.

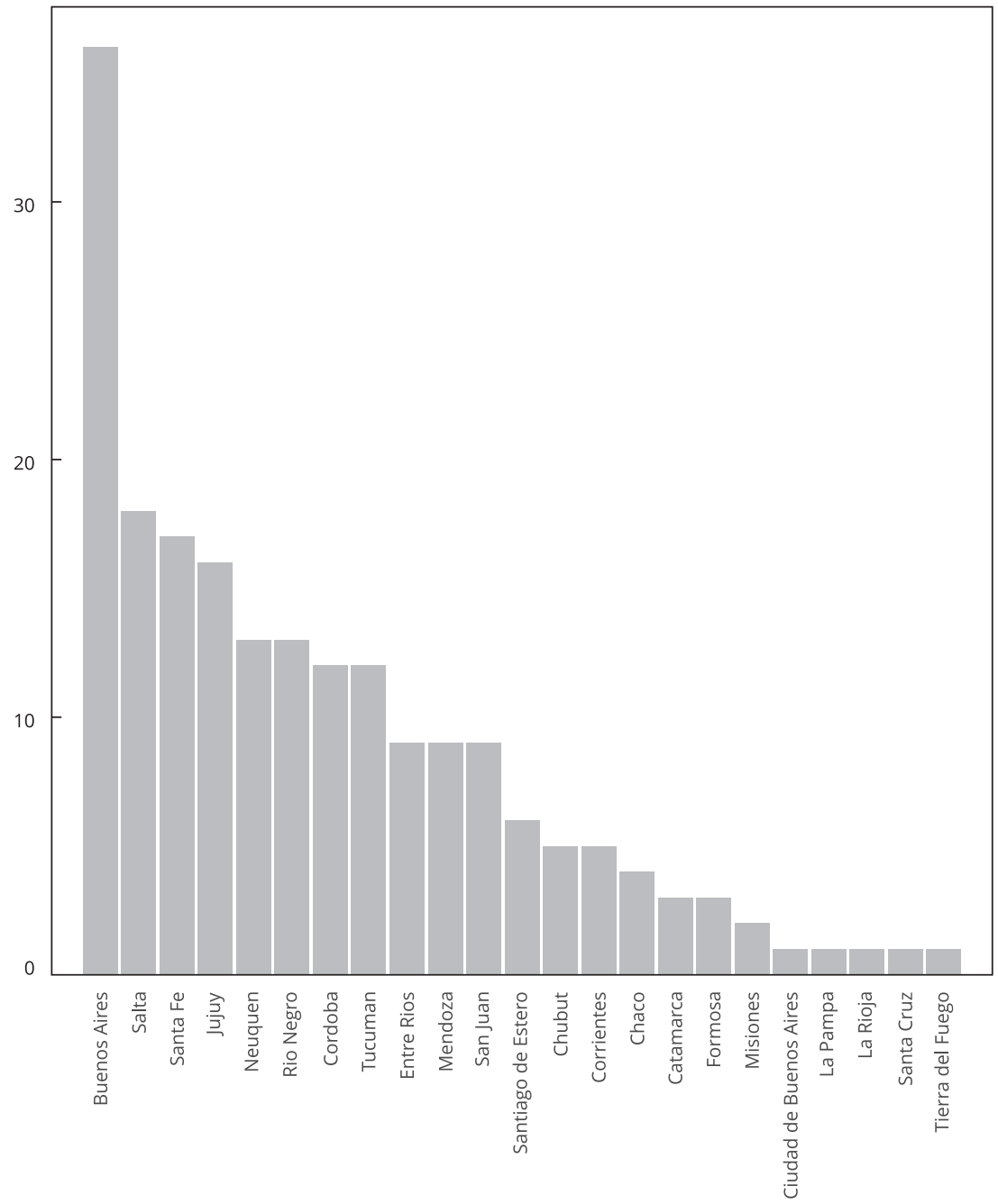

decreasing order, the number of funded proposals per province. The most populated province of Buenos Aires, was granted 36 proposals. At the opposite end of the figure, the city of Buenos Aires, and the provinces of La Pampa, La Rioja, Santa Cruz, and Tierra del Fuego had one funded proposal each.

Each funded project received \$5,000 Argentinian Pesos (equivalent at the time of USD 1,600) to address the health related problem identified as a first priority by the community. Half of the grant was paid to the community in July of 2007 and the other half in the beginning of 2018, upon presentation of the first progress evaluation of the project, which was conducted by the ministry Local Participatory Projects team, the Red Cross, Caritas, or the members of the community. 


\section{The public health problems tackled by the communities}

The first community participation task (required to draft the Local Participatory Projects proposal) was to brainstorm about the community health problems and their causes. Problems were defined as the distance between a real and an ideal situation, where the real situation was considered unsatisfactory. Moreover, as already mentioned, the problem had to be such that it could be addressed (abordable) by community participation. Once the community chose the problem (following the scoring system guidelines), and identified its addressable causes, the next step was to identify strategies and courses of action to address those causes. These courses of action had to be dealt locally, by community participation, and within the limits of the available budget.

Among the funded proposals, the most common problem category was the environment (29\% of the funded projects). These were mostly proposals dealing with garbage treatment, sewage, and sanitation. Next, there were proposals addressing issues pertaining to adolescents (22\%) and prenatal health (18\%). Adolescence problems sometimes had to do with teenage pregnancies as well as problems of youth unemployment. A series of other problem areas followed: chronic health problems ( $14 \%$ of the proposals), violence ( $7 \%$, most common projects referred to family violence), and senior citizens (4\%) among others, as can be appreciated in Figure 3.

Most of these problems reflected the poor communities. Examples of top priority problems in poor or extremely poor communities included: inadequate trash collection and disposal, water contamination, lack of toilets in residences, young children malnourished and not achieving development markers for pre-school admission, prevalence of teen pregnancies, drug use (sometimes by sniffing glue compounds), alcohol abuse by teenagers, lack of recreational opportunities for children and teenagers due to lack of common green areas or facilities such as gyms. In other (small number of) cases, projects sought to address problems related to the old population, such as memory workshops or other recreational activities for the elderly. Interestingly, these projects belong to urban communities, such as Parana in Entre Rios, that we expected to be less afflicted by extreme poverty than rural areas.

\section{Who participates and how often?}

The type of public health problems identified by communities and the supporting materials (photos, for instance) show that the Local Participatory Projects resided largely in poor or extremely poor communities. Moreover, the fact that the PHCC are mostly used by low socioeconomic status Argentinians (those who do not have health coverage by obra social or private health care) meant that the program was by design biased towards that sector of the population.

The original proposals as well as the final reports had to be signed by all the participants present at the meeting in which these documents were drafted. Through the counting of signatures and the coding of names of the signatories by gender, we can calculate the number of participants from civil society present at the moment of the signing of the document and at the time of the final report, as well as their gender.

At the moment of the signing of the project's proposal, an average of 8.5 signatures from civil society members were found across the 201 projects. The project with the highest amount of civil society signatures had 39 -and it was located in Villa San Isidro, Santa Maria, Córdoba- and the sixth lowest ones had none. By the time of the final report, the average number of civil society member's signatures was 6, with a maximum of 29 signatures - PHCC located in San Pedro, Jujuy -, and a minimum of none. For the 112 projects for which there were signatures of civil society members both in the proposal and in the final report, we found that the correlation between the number of participants is positive and statistically significant $(\mathrm{r}=0.29)$.

Regarding gender participation differences, as Figure 4 shows, among civic society participants, women participant signatures were present at a larger ratio than men's signatures. At the time of the proposal design, the ratio was almost 3 women to 1 man (left side of Figure 4). This is particularly significant because the proposal signatures reflect who were present at the time of prioritizing problems within the community, the civil society activity we have called planning. At the time of the final report, the ratio was even larger in favor of women: almost 5 women for 1 man. 
Figure 3

Categories of problems prioritized by communites in Local Participatory Projects (\%).

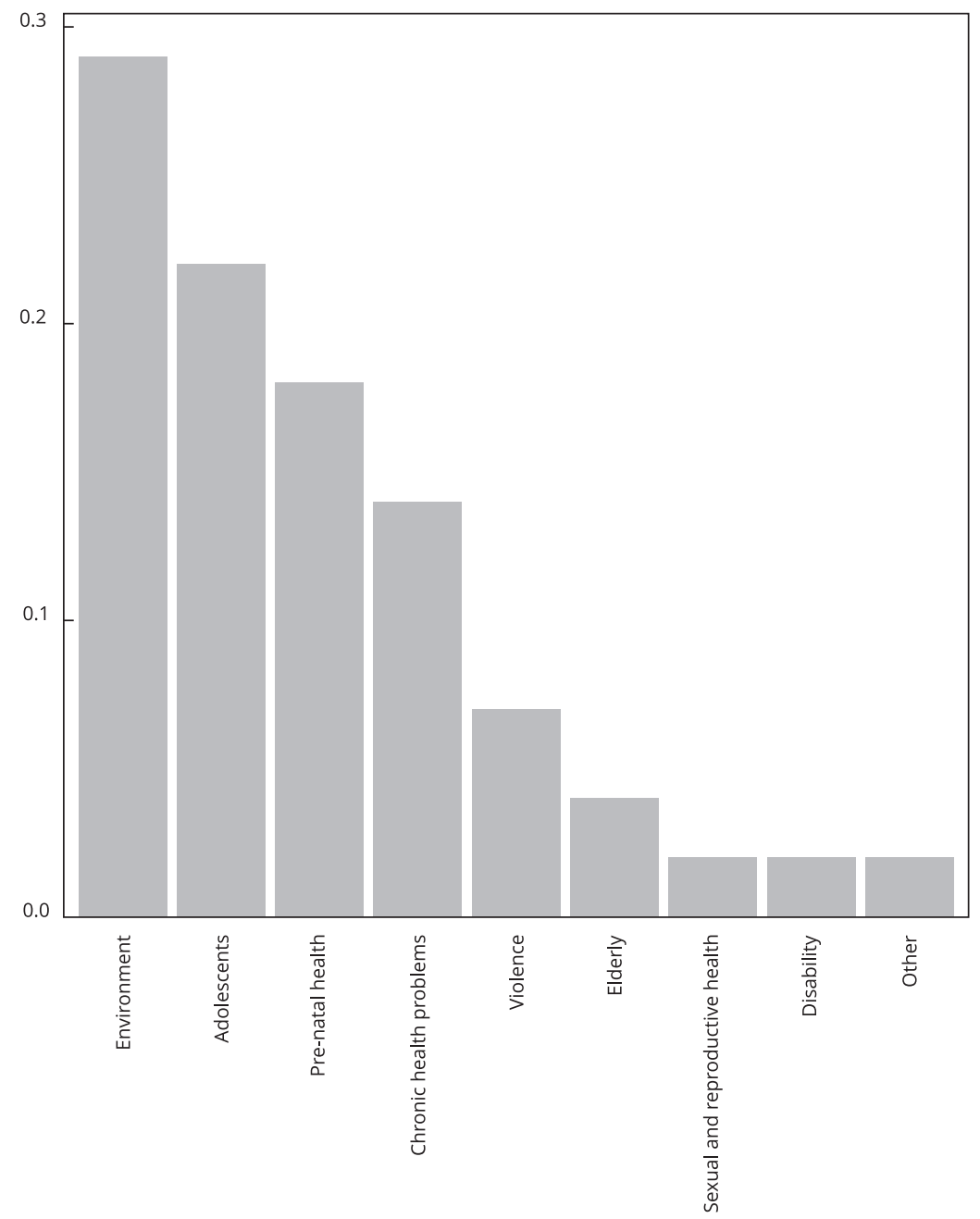

Why did women participate disproportionately more than men in the Local Participatory Projects? We believe this is due to the fact that within the household division of labor health care responsibilities predominantly follow under the purview of the women in the household.

In 121 of the projects carried out, there were meetings held throughout the year. The mode number of meetings held throughout the year is 3 and the median is 6. Few cases, which we call "super participants" and analyze below, had more than one meeting per month (Figure 5). As for the number of civil society participants at these meetings, the average is between 4 and 5 people per meeting, with two outlier cases that had around or over 20 participants per meeting. 


\section{Figure 4}

Local Participatory Projects participants by gender.

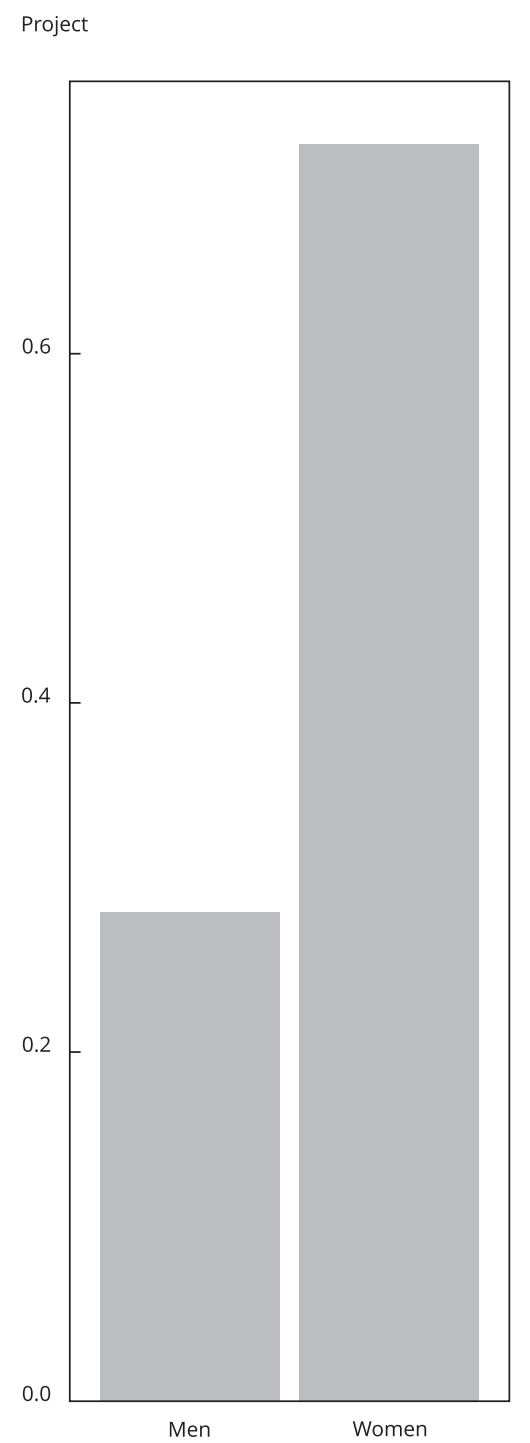

Final report

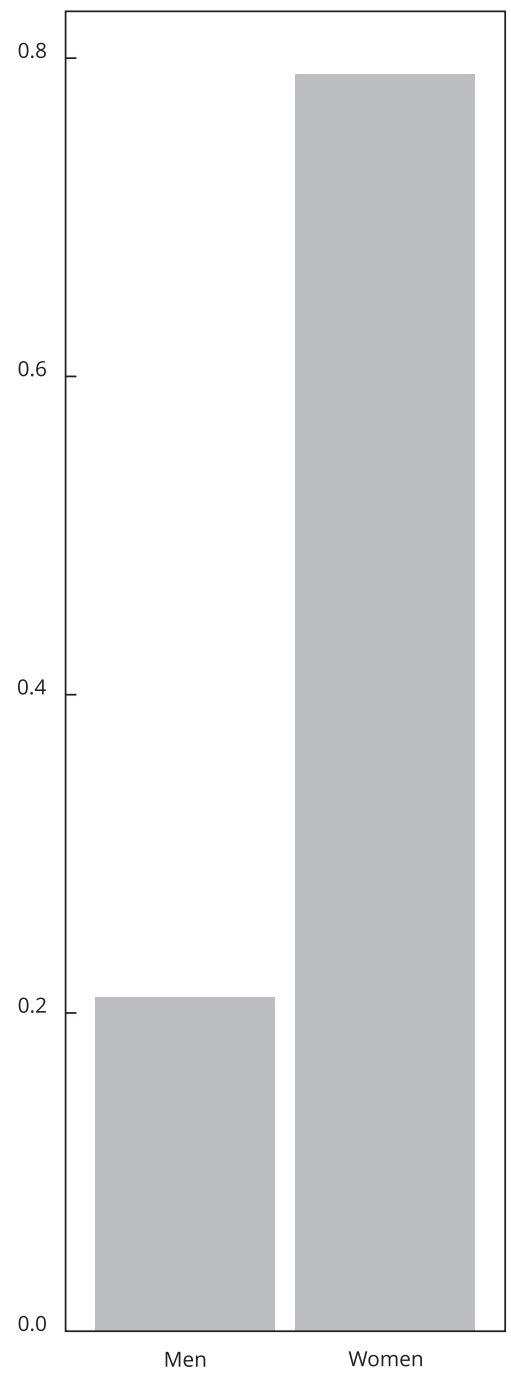

\section{How does programmatic community participation work best?}

The Local Participatory Projects were given a budget and a mandate from the National Ministry of Health to execute that budget and to complete the project within one year. However, as the variable on the percentage of executed budget by the time of the final report shows, there is ample variation among Local Participatory Projects on the amount of the budget that had been spent, ranging from $100 \%$ to $18.5 \%$, with a mean of approximately $80 \%$. Looking closer at some of the Local Participatory Projects reports with unspent money, we found that in some cases communities were extremely careful about expenses, looking for several estimates before proceeding to purchase materials, and sometimes that meant taking more time to execute the budget. This is to say, it is not clear that the budgets' degree of execution is the best indicator to describe efficiency in the project, but is the best 


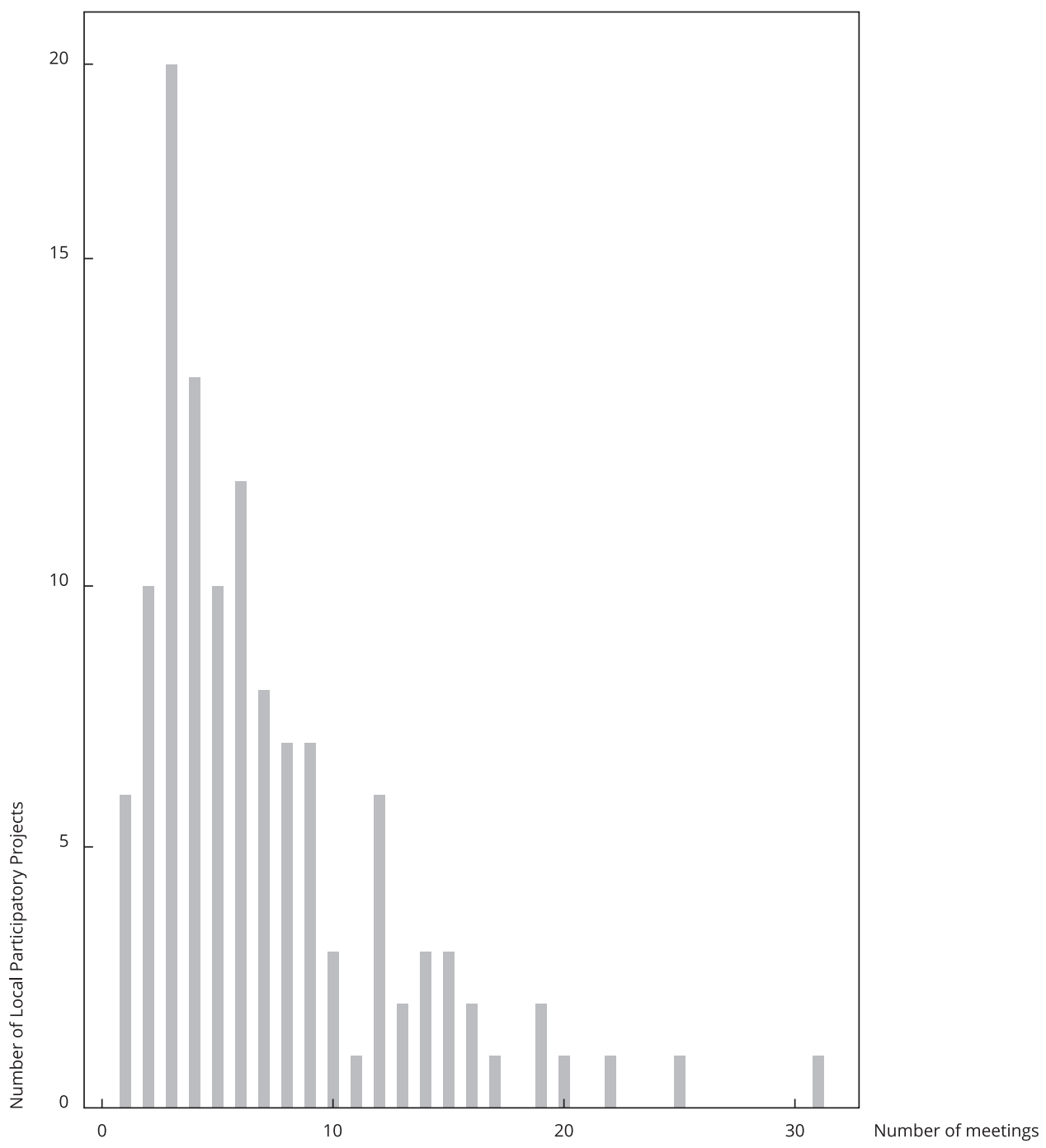

approximate measure we have. Moreover, due to the relatively low number of cases and problems with missing data, we cannot estimate causal statistical models. However, in order to look more closely at the operation of the Local Participatory Projects, we analyzed in further depth those projects that availed a high level of participation of the civil society.

\section{What do we learn from the "super participants"?}

In order to get a better grasp of the type and quality of participation in the Local Participatory Projects we started our analysis by examining the group of programmatic participation community projects we call "super participants." These are the Local Participatory Projects whose members met 15 times or more throughout the year (representing about 5\% of the total number of projects). From an in-depth study of these projects, and based solely on the information collected from the ministry (informed also by our in-depth interviews with national level policy makers), we learn the following. 
First, PHCC' employees act as bridging agents between communities and politicians on the local level. In some contexts (mostly rural), "politicization" is discouraged. For instance, the final report of a Local Participatory Projects in a rural community in the Eastern part of the Southern province of Neuquén (PHCC 3,675, in Los Alamos, Plottier), a community consisting of 268 households that met 25 times throughout the year, stated that the principal problem they encountered was "political". It should be stressed out that interviewees refer to this notion of politicization in order to denounce situations when political parties intended to coopt their community projects. They explained that the project had to be placed in standby during the three months leading to the national elections of October 2007: "The project was in stand-by during the three months of the elections. The political parties approached us and tried to infiltrate us with political punteros [local vote-getters or party brokers], who wanted to make themselves visible to the community. We decided not to be associated with [no quedar pegados] any party in particular and take some time off, instead. (...) From the get go we knew that if we stayed together they couldn't defeat us. There was also the problem of some people who came and only wanted to participate in the project for politics. That was discouraging for us. We believe the decision to [temporarily] stop the project was the correct one. Now the project is in full-steam execution".

The title of this Local Participatory Projects was The Kids Get Lost, Let's Recover Them. The main problem was the lack of activities for the neighborhood's kids and youth, which was located four kilometers from the town center of Plottier. The project sought to rehab a gymnasium that was abandoned and a soccer field. Among other tasks, the participants were able to reach and negotiate with the electrical supplier, so they could provide electricity to the gymnasium. The Local Participatory Projects also offered classes of Taekwondo, soccer, and a music concert throughout the year.

In other Local Participatory Projects, however, the link with and the help from the township was sought after and considered helpful. For example, just in the western outskirts of the city of Buenos Aires, in the Greater Buenos Aires neighborhood of Villa Insuperable, in the locality of La Matanza, Province of Buenos Aires, the members of the Local Participatory Projects, who met 22 times throughout the year, sought the support of the municipality in order to jointly decide the location of a large trash container that was to be built with the Local Participatory Projects funding and the participating community. The local secretary of social development participated in some of the meetings and the PHCC personnel acted as bridgers between the community and the local government.

Second, the programmatic participation of the community in the Local Participatory Projects helps to articulate and voice explicit societal demands towards the local authorities. In both of the Local Participatory Projects just cited (those corresponding to PHCC 3,675 in Neuquén and PHCC 11,590 in the Province of Buenos Aires), even if the approach or relationship with the local political leadership was different, both PHCC worked with the local government to channel the civil society demand for more sports programs in one case and for improving trash collection in the other.

Third, during the execution of the Local Participatory Projects, a certain course of action or communal strategy could often lead to other activities that had not have been originally included in the proposal but that were nonetheless related to the problem tackled by the community and part of its solution. Examples of task transitions include: from treatment of trash disposal to beautification of common green area and flattening of the main dirt road of the neighborhood in the Local Participatory Projects of the PHCC 11,590 in La Matanza, Province of Buenos Aires. Another example was the expansion of activities from the installation of toilets to the issue of cleaning the town's water receptacles. This was the case of the Local Participatory Projects of PHCC 11,361 in Campo Quijano, Rosario de Lerma, Salta. This community met 20 times during the year. They built 23 indoor bathrooms, and later tackled other issues related to the environment.

Fourth, in most projects, there were training or education components such as workshops aimed at the target populations but also at their families, and frequently towards children. In fact, through the Local Participatory Projects, the PHCC often articulate education and play for children. They opened their doors, and went out to the community. Trust between community and the health care personnel increased. The communities also reported feeling more comfortable coming to their PHCC not only when they were sick, but also when seeking vaccination, other preventive care, and for community organization. 


\section{The aftermath of the Local Participatory Projects program}

In 2008, a change in the head of the Ministry meant that the Local Participatory Projects program was placed in standby. In 2009, the Local Participatory Projects leading team proposed to revive the program by targeting the problem of dengue. The country was facing the threat of a dengue epidemic that summer - outbreaks had already taken place in Brazil and in the North of Argentina. The leading authorities of the Ministry agreed to the idea. Thus, the 2009 Local Participatory Projects program was geographically narrowed down to the provinces most likely to be affected by dengue, in the center and north of Argentina.

With this change, the program not only lost geographic coverage, but also its participatory planning component in that it narrowed the scope of problems that communities could seek to address to just one: fighting dengue. While the courses of action and strategies could vary, the prioritization of the problem was given by the state, not the civil society. Thus the program was shifting from a programmatic participatory program for policy-making towards one that was narrower in the scope of civil society activities.

In 2010, in the context of a broader REMEDIAR + REDES program, the Local Participatory Projects national team proposed to articulate community networks, working now, as the REMEDIAR + REDES program was doing, directly with the provincial administrations. One of the shortcomings of the previous years, the national Local Participatory Projects leading team thought, was the lack of articulation between the national government and the PHCC. The expanded REMEDIAR + REDES program provided the institutional "meso" or intermediate infrastructure: the regional or provincial networks that the PLPs could utilize. The funding of international financial institutions (primarily the IADB and the World Bank) were very skeptical of the utility of community participation in health and insisted on evaluating the impact assessments 15 . Nonetheless, they funded the project in 2010 and the Local Participatory Projects were launched in the subset of provinces that had signed for the REDES program. Although by this point the program had lost its national coverage, it passed down the methodology for participatory planning and prioritization of community problems to the provinces.

At the national level, the Local Participatory Projects was again under attack in 2012, and the program was discontinued. In 2015, under the auspices of a new Minister of Health, interested in having the ministry reaching the local territories, the Local Participatory Projects program was revived and the National University of Sarmiento (a public university), in the greater Buenos Aires area became part of the national planning and evaluating team. However, according to different observers the program was by then used mostly for electoral purposes, to continue building support for Cristina Kirchner's government (2007-2011 and 2011-2015) and for Daniel Scioli, who was running as the president's successor candidate in the elections of December of that year. In 2017, the new right wing and conservative government of Mauricio Macri decided to terminate the REMEDIAR program and with that, the Local Participatory Projects program also ended.

The fact that the program was designed and implemented from above meant that once the Ministry of Health and the national government authorities changed, the program could be terminated with the stroke of a pen. There has been some social resistance from PHCC personnel whose payment has been delayed or who are not hired back by the state, but there has not been social mobilization to keep the program in place.

\section{Conclusion}

According to Charles Tilly 15,16 one of the three pre-requisites for democratization is the integration of societal trust networks into the state. In order to democratize, Tilly argues, states must absorb private trust, or, loosely defined, social capital, into the public arena: there must be a broadening popular participation 16 . It is in this process, that civil society is integrated into the state and the state democratizes.

Since the Alma Ata Declaration, community involvement and initiatives to promote citizens' participation have flourished. In a previous work 1, we described how the process of decentralization, was, to a large extent, a condition for the possibility for citizens' participation in public health, both in 
Europe and Latin America. However, not all countries adopted similar types of participatory institutions. While some countries have promoted the involvement of citizens in the design and execution of public health policies (programmatic participation for policy-making), other states have developed institutional frameworks oriented towards listening to the citizens' specific opinions and evaluations on the delivery of public health services (programmatic participation for monitoring) 1 .

Our analysis of Local Participatory Projects in public health in Argentina was framed as a type of community programmatic participation oriented more towards policy-making and less towards monitoring. It has also shown that sectorial elites were instrumental in the process of bringing about participatory institutions, just as Mayka 17 has argued for the case of local health councils in Brazil, and as Harris has documented for the case of health reforms for accessing universalization 18. Progressive policy-makers acting on behalf of the interest of others brought about local participatory projects in Argentina, for instance, or local health councils in Brazil. However, we believe it was precisely the lack of an organized social movement behind those leaders that meant that the Local Participatory Projects program was short lived and highly dependent on the political will of national leaders.

We have also shown that this Local Participatory Projects program targeted poor populations. Unlike other forms of political participation, programmatic participation in public health in the developing world may indeed be a mean for incorporating the population's neediest sectors. We also found that in most poor and rural or semi-urban settings, women participated more both at the stage of prioritizing problems in health as well as at the end of the process. In at least one of the Local Participatory Projects, women reported to feel empowered as a result of the knowledge acquired through the Local Participatory Projects and the new opportunities for leadership and volunteering in their communities. However, such civil society engagement or incorporation is not unmediated. As we found out, health personnel were key brokers (or "bridgers") between communities and the larger bureaucracy of the state in health as well as with the local political authorities. They could keep clientelistic impulses from local politicians at bay and prevent, in some cases, the cooptation of the projects for partisan or particularistic gains.

The analysis of the Local Participatory Projects program also showed the importance of clear, well designed, set of guidelines to prioritize problems, and to identify addressable causes and strategies for programmatic community participatory action. Finally, we found no evidence in the Local Participatory Projects of a synergetic relationship between representatives and citizens required for meaningful participation. The linkage that mattered most was that between community and health care personnel. The relationship with the municipalities or local authorities was synergetic and productive at times, or conflict-ridden and unproductive in other cases. In either case, the degree of community involvement in the project and its successful implementation was not correlated with the participation of municipal authorities - in fact, the participation of the local church in the project was the only variable that reached statistical and positive correlation with the execution of the projects.

Is programmatic participation in health a panacea? Certainly not. Participation does not always mean inclusion. Several scholars highlighted the problem of biased representation towards health providers or patients' organizations with more knowledge and resources, for instance. In the case of Local Participatory Projects in Argentina, we also found that the relationship between programmatic community participation at the local level and political leadership is a complex one. Threatened by rising leaderships, local political leaders may compete with programmatic participation or attempt to coopt it. More research is necessary to better understand the local context conditions that lead to either collaborative or competitive incentives between organized communities and local politicians. Despite these areas of uncertainty, the Local Participatory Projects in Argentina did bring, through programmatic community participation, coordinated by the health personnel, solutions to communities that badly needed them and provided them with tools for organization that survived the scope of the projects. These results possibly bode well for those institutional innovations for community participation in public health systems that were brought about by political reform processes. It also shows the potential that institutions of programmatic participation for civic monitoring may have if they are expanded to include more civil society activities and to grant civil society more of a role in policy-making. 


\section{Contributors}

T. G. Falleti was responsible for the data collection. T. Falleti and S. L. Cunial shared responsibility for data analysis and writing.

\section{Additional informations}

ORCID: Tulia G. Falleti (0000-0002-0995-4682);

Santiago L. Cunial (0000-0002-4657-7388).

\section{Acknowledgments}

We are grateful to Luis Caiella, Luis Cecchi, Emmerich Davies, Galileu Kim, Yasmín Mertehikian, and Sara Niedzwiecki for their research assistance. We are also grateful to all the interviewees, who were exceedingly generous in sharing their knowledge about community participation; to Carlos Anigstein and Federico Tobar, who also provided relevant documents and bibliography; and to the authorities of the National Ministry of Health of Argentina, who granted us access to the 2007 local participatory projects' archives. Two CSP anonymous reviewers provided helpful comments that improved our article.

\section{References}

1. Falleti TG, Cunial S. Participation in social policy: public health in comparative perspective. Cambridge: Cambridge University Press; 2018. (Elements in the Politics of Development).

2. Carpenter D. Is health politics different? Annu Rev Polit Sci (Palo Alto) 2012; 15:287-311.

3. Altschuler D, Corrales J. The spillover effects of participatory governance: evidence from community-managed schools in Honduras and Guatemala. Comp Polit Stud 2012; 45:636-66.

4. Gonzalez Y. Varieties of Participatory Security: Assessing Community Participation in Policing in Latin America. Public Adm Dev 2016; 26:132-43.

5. Abers RN, Keck ME. Practical authority. Agency and institutional change in Brazilian water politics. New York: Oxford University Press; 2013.

6. Pogrebinschi T, Samuels D. The impact of participatory democracy: evidence from Brazil's National Public Policy Conferences. Comp Polit 2014; 46:313-32.

7. Cetrángolo O, Jiménez JP. Política fiscal en Argentina durante el régimen de convertibilidad. Santiago de Chile: Comisión Económica para America Latina y Caribe, Naciones Unidas; 2013.

8. Eaton K. Politicians and economic reform in new democracies: Argentina and the Philippines in the 1990s. University Park: Pennsylvania State University Press; 2002.

9. Eaton K. Politics beyond the capital: the design of subnational institutions in South America. Stanford: Stanford University Press; 2004.
10. Falleti TG. Decentralization and subnational politics in Latin America. New York: Cambridge University Press; 2010.

11. Tobar F. Descentralización y reformas de salud en América Latina. In: Yadón Z, editor. Descentralización y gestión del control de las enfermedades transmisibles in América Latina. Buenos Aires: Organización Panamericana de la Salud; 2006. p. 65-114.

12. Berlotto A, Fuks A, Rovere M. Atención primaria de salud en Argentina: proliferación desordenada y modelos en conflicto. Saúde Debate 2012; 36:362-74

13. Programa REDES. REMEDIAR+REDES: 10 años comprometidos con la salud pública. Buenos Aires: Ministerio de Salud; 2012.

14. REMEDIAR; Programa Médicos Comunitarios; Red Argentina de Municipios y Comunidades; Munisterio de Salud. Guía de planificación local participativa. http://municipios.unq edu.ar/modules/mislibros/archivos/Gu\%EDa. pdf (accessed on Dec/2018).

15. Tilly C. Trust and rule. New York: Cambridge University Press; 2005.

16. Tilly C. Democratization. New York: Cambridge University Press; 2007.

17. Mayka L. Building participatory institutions in Latin America: reform coalitions and institutional change. New York: Cambridge University Press; 2019.

18. Harris J. Achieving access: professional movements and the politics of health universalism. Ithaca: Cornell University Press; 2017. 


\section{Resumen}

Desde la Conferencia de la Organización Mundial de la Salud de Alma Ata en 1978, varios países alrededor del mundo han creado instituciones que promueven la participación de la ciudadanía en sus sistemas públicos de salud. En este artículo, en primer lugar, describimos los orígenes e implementación de un programa cívico participativo en el territorio nacional, que se realizó en Argentina a mediados de la década de los años 2000, denominado Proyectos Locales Participativos; en segundo lugar, analizamos 201 proyectos locales participativos que se llevaron a cabo en el país entre 2007 y 2008. Estudiamos los problemas de salud y medioambientales que motivaron la participación de la gente en el programa, así como la dinámica social a través de la cual se canalizaba esta participación.

Participación de la Comunidad; Planificación en Salud; Gobierno Local; Política de Salud

\section{Resumo}

Desde a Conferência de Alma Ata da Organização Mundial da Saúde em 1978, países do mundo inteiro adotaram instituições que promovem a participação dos cidadãos nos sistemas de saúde pública. O artigo teve dois objetivos principais. Primeiro, descrevemos as origens e a implementação de um programa participativo em nível nacional que foi implementado na Argentina em meados da primeira década deste século: os chamados Projetos Locais Participativos (Proyectos Locales Participativos). Segundo, analisamos os 201 projetos de participação local que foram implementados na Argentina entre 2007 e 2008. Estudamos os problemas sanitários e ambientais que motivaram a participação popular no programa e a dinâmica social através da qual essa participação é efetivada.

Participação da Comunidade; Planejamento em Saúde; Governo Local; Política de Saúde
Submitted on $17 / \mathrm{Dec} / 2018$

Final version resubmitted on 11/Apr/2019

Approved on 15/Apr/2019 